who recommended him to the trustees of this hospital, and he proved a worthy successor of the men who had preceded him. At the time of his appointment he was 34 years of age, and he occupied the post for a little more than two years, namely, from December, 1885, to March, 1888. It is stated that "during this brief period he had performed the difficult duties of his position with signal abilities and success, and had won for himself the entire confidence and the warm esteem of the trustees and friends of the hospital, while the innate kindliness of his spirit and the gentleness of his manners were widely felt among its inmates. He came here with a high reputation, which he has fully sustained and extended during his brief residence in Providence. In the special department of the medical world to which he was devoted, he already held a place in the foremost ranks. His training had been thorough and diversified, his experience large and varied, and his qualifications for the difficult position which he filled were of the highest order. His unexpected death will bring sorrow, not only to those with whom he was more immediately associated in the management of the hospital, but to all who estimate aright the importance of high professional character and acquirements to the entire community."

The cause of death was pneumonia, which lasted for a week. He suffered severe pleuritic pain; the highest temperature was $104^{\circ}$, his pulse frequent and weak, and he became much prostrated. In addition to the medical advice afforded by the city, the services of Drs. Folsom and Shattuck were obtained, and the former sat up with him during the night. He himself remarked during his illness: "One thing is against me, I have a bad heart." Subsequently he said to his sister, "The crisis has come, and I hope to get well, but there is doubt." Several days before he died he said with his characteristic cheerfulness, "It must be all for the best."

One of the Governors of the New York Hospital and Bloomingdale Asylum writes: "The death of Dr. Goldsmith is to me a loss of a warm personal friend. I have been greatly drawn to him during the past two years; a most judicious, earnest friend, full of talent, self-reliant, most honourable, and alive to any advanced professional work." The same hand writes: "The service in the chapel was of the most simple character, directed by Dr. Goldsmith himself. He awaited death with supreme courage, and it was only the day before, that he gave up the hope that he would survive. The grief of everyone, from the trustees to the labouring men on the place, was most sincere."

To him may be applied the lines of his friend Whittier-

" His daily prayer, far better understood

In acts than words, was simply doing good,

So calm, so constant was his rectitude,

That by his loss alone we know its worth,

And feel how true a man has walked with us on earth."

Dr. Goldsmith died unmarried, and leaves a widowed mother and a sister to mourn his untimely loss, for whom we venture to express our warm sympathy.

\title{
W. DEAN FAIRLESS, M.D.
}

A man's worth is not to be determined by the prominence of his position or the brilliancy of his success, for the best men are often the least prominent, and to deserve high success is better even than to attain it.

This is the feeling with which all who really knew him will recall $\mathrm{Wm}$. Dean Fairless and the story of his life. Having become M.D. of St. Andrew's and M.R.C.S.England, he began his professional life at Crieff, in Perthshire, where he practised with great acceptance for seven years. He left Crieff on account of his wife's health amid general regret, and began work in his native town, Hexham, Northumberland, where his ancestors were well and honour- 
ably known. He soon found that the toil of country practice was beyond his strength, and turned his attention to lunacy, becoming in 1859 assistant to Dr. Howden, of the Royal Lunatic Asylum, Montrose. On the completion of the buildings at Sunnyside, which now bear that name, Dr. Fairless was appointed Medical Superintendent of the Old Asylum in the town of Montrose, and filled that office ably and efficiently for about six years. Nor was he merely an asylum superintendent, for wherever he resided he took an active part in all the agencies for the intellectual and moral elevation of his fellow citizens.

When the Old Asylum at Montrose was closed, Dr. Fairless resided for a time at Conparangus, while looking for more work in connection with the insane, and eventually selected Lanarkshire, where he built and superintended the Kirklands Asylum at Bothwell. The eleven years he spent at Bothwell were probably the best of his life. His personal character and mature experience made him a most kind and skilful asylum physician, while he used his institution as a means of doing good rather than of making money. $\mathrm{He}$ was honoured by his professional brethren, and for years was Secretary of the Scottish Midland and Western Medical Association. He was held in very high esteem by the friends of patients, and by all who knew him, and at Bothwell, as well as at Crieff and Conparangus, presentations of valuable gifts were made to him by the public, expressive of the general esteem.

In 1879 he sold Kirklands to the District Board of Lunacy, and, retiring from medical work, resided first in Oxford and latterly in London, where he died on April 4th, 1888, from cardiac and renal disease, in his 66th year. His death is mourned by a widow and six children, and by many old friends.

In his manner he was kind, gentle, and sensitive, in his work patient, painstaking, and anxious, while his whole life was elevated and sustained by the highest moral tone.

His later days were clouded by much domestic affliction and by unfortunate money investments, as well as by much personal suffering, but through them all he was the same gentle, patient,'self-forgetting, God-fearing man-to whom to die was gain.-D. Y.

\section{THOMAS HARRINGTON TUKE, M.D., F.R.C.P.}

We greatly regret to have to record the death of a member and former officer of the Medico-Psychological Association, Dr. T. Harrington Tuke, who died of pulmonary disease at his residence, the Manor House, Chiswick, June 9th, 1888. He came of a good Irish family, and traced his ancestors to the West of Ireland, where they resided for several generations at Tralee, and subsequently in Dublin, the birth-place of his father, Dr. Edward Francis Tuke. His son was born at Bristol, June 13th, 1828. He was educated privately, and at Kensington School. He studied medicine at St. George's Hospital, passed the College of Surgeons in 1847, and became M.D. St. Andrew's in 1849. He obtained the Fellowship of the College of Physicians in 1868. His connection with the Private Asylum at the Manor House, Chiswick, dated back to the time of his father's death in 1846, when, in conjunction with his mother, a lady remarkably gifted with administrative powers, he took charge of the house. The establishment was conducted on a liberal scale, and the enemies of licensed houses never brought any charge against the mode in which the Manor House was carried on, either in regard to the dietary or the treatment of the patients. Dr. Harrington Tuke was generous indeed, to the point of being lavish, and crippled his own resources thereby. His manner towards the patients under his care was frank and kindly, and he displayed much tact in eluding the inconvenient questions which the insane are so well able to put to the mental physician. 